Review Paper

\title{
Methane emissions from northern lakes under climate change: a review
}

\author{
Lingling $\mathrm{Li}^{1} \cdot \operatorname{Bin} \mathrm{Xue}^{2}$
}

Received: 23 November 2020 / Accepted: 8 November 2021

Published online: 24 November 2021

(c) The Author(s) 2021 OPEN

\begin{abstract}
Northern lakes are important sources of $\mathrm{CH}_{4}$ in the atmosphere under the background of permafrost thaw and winter warming. We synthesize studies on thermokarst lakes, including various carbon sources for $\mathrm{CH}_{4}$ emission and the influence of thermokarst drainage on carbon emission, to show the evasion potential of ancient carbon that stored in the permafrost and $\mathrm{CH}_{4}$ emission dynamics along with thermokarst lake evolution. Besides, we discuss the lake $\mathrm{CH}_{4}$ dynamics in seasonally ice-covered lakes, especially for under-ice $\mathrm{CH}_{4}$ accumulation and emission during spring ice melt and the possible influential factors for $\mathrm{CH}_{4}$ emission in ice-melt period. We summarize the latest findings and point out that further research should be conducted to investigate the possibility of abundant ancient carbon emission from thermokarst lakes under climate warming and quantify the contribution of ice-melt $\mathrm{CH}_{4}$ emission from northern lakes on a large scale.
\end{abstract}

Keywords $\mathrm{CH}_{4}$ emission $\cdot$ Northern lakes $\cdot$ Permafrost thaw $\cdot$ Ice coverage $\cdot$ Climate change

\section{Introduction}

Atmospheric $\mathrm{CH}_{4}$ is the second major greenhouse gas, with 32 times higher global-warming potential than $\mathrm{CO}_{2}$ for a 100-year time horizon, and contributes to about $23 \%$ to the additional radiative forcing accumulated in the lower atmosphere since 1750 [25]. Over the past two decades, surface freshwaters including lakes, reservoirs, and rivers have been recognized as important global $\mathrm{CH}_{4}$ sources $[4,70]$, whereas the contribution of northern lakes is neglected and overshadowed by wetland emission [11, 96]. In the northern high-latitude regions, temperatures have risen $0.6^{\circ} \mathrm{C}$ per decade over the last 30 years, which is twice as fast as the global average [32]. This is combined with the increase in permafrost degeneration [1] and rapid warming of lake surface water [63]. Under this background, a growing number of studies had started to pay attention to the role of northern freshwaters (lakes and ponds) in $\mathrm{CH}_{4}$ emissions. The themes are focused on the following:

I. $\mathrm{CH}_{4}$ emissions from northern thermokarst lakes. Thermokarst lakes can mobilize deeper permafrost stored organic matter, especially for the mineralization of Pleistocene-aged carbon, which may result in positive warming feedback of climate change [76]. However, more research suggests that the permafrost carbon feedback is the synergies of thermokarst lake formation, extension, drainage, and vegetation resume processes (e.g., [22, 87].

II. $\mathrm{CH}_{4}$ emissions in the seasonally ice-covered lakes. In northern lakes, a significant part of the annual flux occurs

Supplementary Information The online version contains supplementary material available at https://doi.org/10.1007/s42452-02104869-x.

$\triangle$ Bin Xue, bxue@niglas.ac.cn | ${ }^{1}$ College of Urban Resource and Environmental Sciences, Jiangsu Second Normal University, Nanjing, China. ${ }^{2}$ State Key Laboratory of Lake Science and Environment, Nanjing Institute of Geography and Limnology, Chinese Academy of Sciences, Nanjing, China.

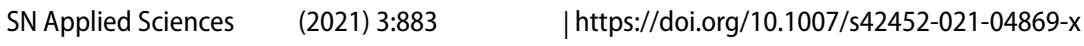


during the ice-melt period in spring $[34,43,56]$ besides the autumn overturn period for dimictic lakes [26]. Hence, the winter ice-covered period is recognized as an accumulation season of $\mathrm{CH}_{4}$, and knowledge about the importance of lake carbon cycle in the ice-covered period is important to understand present-day conditions and predict the effects of climate change on aquatic systems and the referring feedback effects on the climate [43].

Here, we review the increasing knowledge on $\mathrm{CH}_{4}$ emissions from northern lakes and provide expectations for future studies.

\section{Thermokarst lake dynamics and $\mathrm{CH}_{4}$ emission feedback}

\subsection{Permafrost thaw and thermokarst lake formation}

Permafrost is defined as ground that remains at or below $0{ }^{\circ} \mathrm{C}$ for at least two consecutive years (Permafrost Subcommittee, 1988) and is estimated to occupy about $24 \%$ of the northern hemisphere land area, with approximately $70 \%$ distributed between $45^{\circ} \mathrm{N}$ and $67^{\circ} \mathrm{N}$ [97]. Permafrost warming continues along with the increase in air temperature. Near-surface permafrost in the High Arctic and other very cold areas has warmed by more than $0.5^{\circ} \mathrm{C}$ since $2007-2009$, and the layer of the ground that thaws in summer, which is usually identified as active layer, has deepened in most areas where permafrost is monitored [1]. Permafrost in the subarctic zone, where the permanently frozen ground is discontinuous, is especially vulnerable to environmental change as it is already close to its thawing point [61]. While even in the Arctic zone of continuous permafrost, an abrupt, large increase in the extent of permafrost degradation has been observed [36].

Thermokarst is the process by which the thawing permafrost ground causes land subsidence, resulting in development of distinctive landforms $[46,76]$. Thermokarst formation has important impacts on the hydrology, geomorphology, biogeochemistry, and ecology of the Arctic landscape [8], which will be accelerated under climate change [62]. For example, lakes are formed in the thermokarst landforms following thawing of ice-rich permafrost or melting of massive ground ice and snow [29]. Thermokarst lakes are widespread throughout the Arctic and subarctic lowland areas of western and northern Alaska [64], northern Scandinavia [14], Canada [9], and Siberia [59]. For example, thermokarst lakes comprise approximately $90 \%$ of the lakes in the Russian permafrost zone [88], and thermokarst can affect $10-30 \%$ of Arctic lowland landscapes in northern Alaska [36].

Thermokarst lakes could bring positive feedbacks to permafrost thaw as permafrost thaw is much deeper under lakes than under terrestrial soils [74, 99]. Thawed water enhances heat flow into the upper permafrost, leading to the thawing of previously frozen soil. If lakes deepen past the maximum depths of winter ice, which are approximately 1.5-2 $\mathrm{m}$ in the outer Alaskan Arctic Coastal Plain [2], they maintain a perennially unfrozen pool of liquid water and thawed sediment, which is termed as talik (Fig. 1). The
Fig. 1 Schematic showing the thaw-lake $\mathrm{CH}_{4}$ production by organic carbon of different ages. The supply of $\mathrm{H}$ to $\mathrm{CH}_{4}$ production by Late Pleistocene carbon occurs along thermokarst erosion margins, and the radiocarbon age of $\mathrm{CH}_{4}$ tend to be younger (e.g., Holoceneaged) toward the lake center. The figure is modified from Brosius et al. [10]

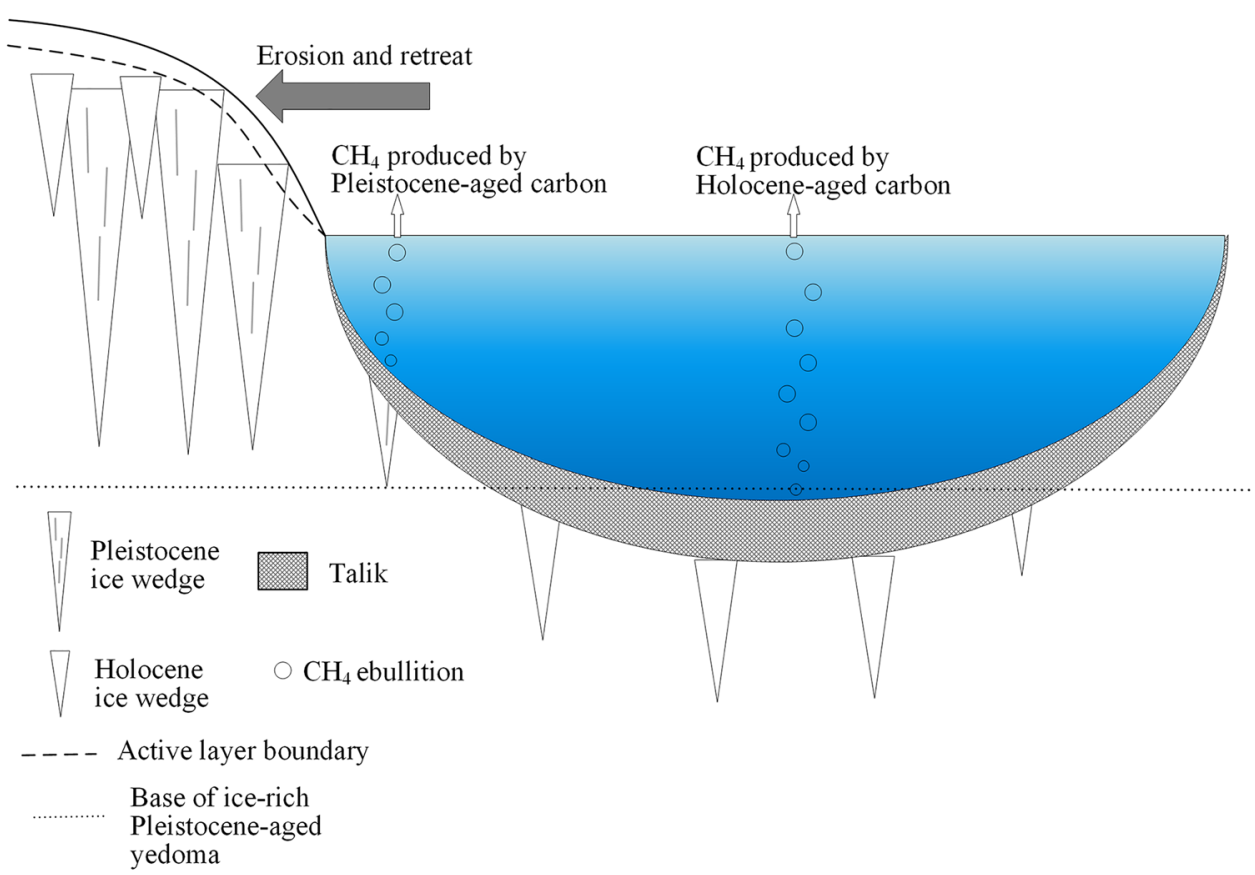


talik can deepen and expose the formerly sequestered organic carbon to microbial activity [2].

Besides of the strong influence on the surface energy balance in permafrost regions $[12,38]$, thermokarst lakes are also considered to be potential sources of greenhouse gas, which may result in positive warming feedback of climate [76]. Permafrost soils store more carbon than that currently present in the atmosphere and all living biomass combined, which has accumulated for over tens of thousands of years as senesced plant materials are frozen and preserved $[97,98]$. Thermokarst lakes can mobilize deeper permafrost stored organic carbon and anaerobic environments in the lake bottoms result in the microbial decomposition of organic matter and $\mathrm{CH}_{4}$ production and emission $[88,89]$. Thermokarst lakes were found to be $\mathrm{CH}_{4}$ emission hotspots in the northern area [96] and experts assessment revealed that a third to a half of expect climate forcing of permafrost change is from $\mathrm{CH}_{4}$ [75]. Focusing on the theme of permafrost $\mathrm{CH}_{4}$ feedback, future studies should answer the following questions: (1) whether massive old carbon (Pleistocene age) stored in the permafrost will be emitted as $\mathrm{CH}_{4}$, and (2) how future thermokarst lake dynamics (drainage or extension) would affect $\mathrm{CH}_{4}$ emissions.

\subsection{Carbon source for $\mathrm{CH}_{4}$ emission: old versus young carbon}

Regions that remained unglaciated throughout the last glacial maximum accumulated thicker sediments and abundant frozen organic carbon. Among these sediments is one carbon and ice-rich silty loess that termed as yedoma in Siberia, which represents an organic-rich $(\sim 2 \%$ carbon by weight) Pleistocene-aged loess permafrost with a total volumetric ground ice content likely ranges from 65 to $90 \%[73,80]$. Yedoma covered more than 1 million $\mathrm{km}^{2}$ of the north plain of Siberia and Central Alaska to an average depth of $\sim 20 \mathrm{~m}[80,99]$. These sediments had carbon contents about 10 to 30 times the amount of carbon generally found in deep, non-permafrost soils. Although yedoma deposits cover only $6 \%$ of the global permafrost area, they may store around $20 \%$ of all permafrost carbon [80].

Yedoma sediments began melting during the Holocene to form thermokarst lakes, where $\mathrm{CH}_{4}$ is produced and released primarily by bubbling $[88,99$. A study of 40 lakes in Alaska showed that $\mathrm{CH}_{4}$ emissions from the thermokarst lakes formed in yedoma permafrost soils are much higher than from non-yedoma lakes [78]. Since the high carbon content of Pleistocene-aged permafrost soils, especially for the yedoma region, thermokarst lake was thought to be a canal of the release of old carbon stocks previously stored in permafrost. Experiments showed that the Pleistocene carbon in yedoma soils could lost quite quickly when permafrost thawed [98], and stable isotopes and radiocarbon analyses indicated the distinct $\delta^{13} \mathrm{C}$ and ${ }^{14} \mathrm{C}$-depleted carbon source $\left(\delta^{13} \mathrm{CH}_{4}=-70 \%,{ }^{14} \mathrm{C}\right.$ age 16,500 years) for $\mathrm{CH}_{4}$ production in North Siberian lakes, suggesting that continued warming of permafrost in the future could lead to accelerated release of ${ }^{14} \mathrm{C}$-depleted $\mathrm{CH}_{4}$ (i.e., ancient carbon) from expanding thermokarst lakes [90].

Recently, substrate sources for $\mathrm{CH}_{4}$ production in the permafrost thaw area have been more precisely investigated. Melt water from permafrost ice serves as $\mathrm{H}$ source for $\mathrm{CH}_{4}$ production in thermokarst lakes. Based on $\delta \mathrm{D}_{\mathrm{CH} 4}$ measurements, researchers found that Late Pleistoceneaged permafrost ground ice is the dominant $\mathrm{H}$ source of $\mathrm{CH}_{4}$ production in primary (i.e., first-generation) thermokarst lakes, whereas after evolution through lake drainage and reformation, etc. [37], $\mathrm{H}$ source of $\mathrm{CH}_{4}$ in the later generation lakes is primarily from Holocene-aged permafrost ground ice [10]. Besides, the carbon source is also varying in thermokarst lakes. The carbon trajectories for yedoma-region thermokarst basins showed the peak flux of yedoma carbon (e.g., old carbon) at the peak formation of thermokarst lake during deglaciation [93]. An extensive investigation of thermokarst lakes in Alaska, Canada, Sweden, and Siberia revealed that $\mathrm{CH}_{4}$ emissions from thermokarst lakes are directly proportional to the mass of soil carbon inputs to the lakes from the erosion of thawing permafrost. Moreover, late Pleistocene-aged yedoma soil organic carbon is released in high-flux hotspot seeps located in thermokarst expansion zones, or along boundaries of thawing permafrost, whereas $\mathrm{CH}_{4}$ from seeps in other zones of yedoma lakes has relatively younger age $[92,94]$. Thus, the radiocarbon age of $\mathrm{CH}_{4}$ is the oldest along thermokarst erosion margins and tends to be younger with increased distance toward the lake center (Fig. 1) $[10,44,94]$.

However, a recent study on lakes in Alaska's North Slope found that lake carbon emissions primarily originate from the degradation of recently formed terrestrial carbon, and Pleistocene carbon has only minor contributions [22]. Moreover, they found that the decomposition and emission of ancient carbon are the greatest from the lakes in the coastal plain geology unit, which maintains the combination of warming temperatures, ancient carbon storage, and the development of new or expanding taliks in the thermokarst [22]. Besides, through incubation experiments, Knoblauch et al. [45] pointed out that $\mathrm{CH}_{4}$ emission in permafrost deposits is not decided by age but instead depends on the organic matter concentration and quality that formed under different past climatic conditions. Recently, a synthesis of ${ }^{14} \mathrm{C}$ measurements from the northern permafrost region showed that the age of $\mathrm{CH}_{4}$ emitted from lakes depended primarily on the age and quantity 
of soil organic carbon in sediments and on the mode of emission [24], since lake ebullition $\mathrm{CH}_{4}$ was dominated by old carbon especially in high-emission point, while lakes showed much younger diffusive $\mathrm{CH}_{4}$ fluxes $[24,58]$. Therefore, whether relatively fresh and young carbon or ancient permafrost carbon dominates $\mathrm{CH}_{4}$ production in Arctic lakes may vary among lakes and regions, so future studies must consider permafrost thawing and lake-forming processes, as well as permafrost topographical, geological, and organic matter characteristics.

\subsection{Thermokarst drainage and carbon emission}

Although increased surface ponding in warming permafrost environments driven by slumping and collapsed terrain features that subsequently fill with water is expected, satellite images of regions rich in thermokarst lakes in many regions show numerous drained and vegetated lake basins, generally exceeding the number and area of extant lakes [29]. The water-level decline and lake shrinkage mainly occur in the southerly zones of discontinuous, sporadic, and isolated permafrost, while the continuous zone is experiencing lake expansion or no significant change $[13,79]$. Such differences in observations can be explained if the processes are considered as a continuum, i.e., initial development of thermokarst and lake expansion caused by warming, followed by a reduction in lake surface area to complete subsurface drainage as the permafrost warms and degrades further, allowing hydrological connections between surface and underground flows through portions of unfrozen ground [79]. Lateral drainage caused by lakeshore breaching has also been reported even in the continuous permafrost zone [29]. The dynamics of thaw lakes are markedly influenced by local topography; in low-relief topography, the lake is simulated to expand rapidly and fully drained, while in a high-relief-topography, lake grows slowly and continuously and is only partial drained [44].

Lake drainage causes lake shrinkage and water-level decrease, even return lake area to terrestrial wetland areas, which has a profound impact on the carbon cycle. Previous studies found $\mathrm{CH}_{4}$ flux in the floodplain of the eastern Siberia decrease rapidly with lower water table, while it serves as a large $\mathrm{CO}_{2} \operatorname{sink}[85,86]$. An investigation in Québec, Canada, revealed that permafrost thawing is not primarily accompanied with an increase in thermokarst lakes, but rather with a remarkable increase in vegetation cover [7]. The degradation of permafrost stimulates net carbon storage in the wooded boreal peatlands [84]. Peat accumulation rates were highest in young (50-500 years) drained lake basins, which stores organic carbon that likely offset greenhouse gas release from thermokarst-impacted landscapes [35]. Above all, [93] proved a shift of thermokarst lakes from carbon sources to sinks during the Holocene epoch accompanied by lake drainage and they considered that lake drainage lowers lake water level, slowing thermokarst and stimulating growth of benthic mosses and other plants. In summary, expanding thermokarst lakes can result in carbon evasion by exposing substantial quantities of organic matter to decomposition by microbes, whereas lower near-future $\mathrm{CH}_{4}$ emissions from these landscapes than previously assumed were predicted due to lake drainage, and the drained or shrinking water masses act as net carbon sinks (at least for $\mathrm{CO}_{2}$ ) when vegetation resumes and peat accumulates in old lakebeds [87].

Besides of hydrology, lake drainage could also change the redox condition in the permafrost region. Drained lakes may shift from being a source of $\mathrm{CH}_{4}$ to being a source of $\mathrm{CO}_{2}$, whereas $\mathrm{CH}_{4}$ release decreases due to oxidation or the inhibition of $\mathrm{CH}_{4}$ production [87]. Nevertheless, considering the greater $\mathrm{CH}_{4}$ global-warming potential than $\mathrm{CO}_{2}$, the full magnitude of the climate effect from thermokarst lake drainage depends on the comprehensive estimation of carbon emission and their warming potential. By incubating the permafrost soils in aerobic and anaerobic conditions separately in $15^{\circ} \mathrm{C}$ for 500 days, Lee et al. [49] showed that permafrost carbon in a relatively aerobic ecosystems may have a greater effect on climate. The similar method was used by Knoblauch et al. [45] for a 1200 days incubation in $4{ }^{\circ} \mathrm{C}$, which found only $25 \%$ of aerobically mineralized carbon was released in the absence of oxygen. Besides, Schuur et al. [76] compared the results from the aerobic permafrost soil incubation [71] with those from another anaerobic incubations [83] and reported $78-85 \%$ lower carbon emissions in anaerobic soils than in aerobic ones. More importantly, a long-term incubation ( $>12$ years) showed that carbon at near-saturated conditions may remain largely immobilized over decades [21]. Moreover, even when accounting for the higher global warming potential of $\mathrm{CH}_{4}$ relative to $\mathrm{CO}_{2}$, the ratio of aerobic to anaerobic $\mathrm{CO}_{2}-\mathrm{C}$ equivalent (sum of $\mathrm{CO}_{2}-\mathrm{C}$ plus $\mathrm{CH}_{4}-\mathrm{C}$ expressed as $\mathrm{CO}_{2}-\mathrm{C}$ equivalent) was 2.3 times higher in fully aerobic soils than under anaerobic conditions [72]. Hence, a unit of newly thawed permafrost carbon could have a greater impact on climate over a century if it thaws and decomposes within drier, more aerobic soil than an equivalent amount of carbon within waterlogged soil or sediment [76]. In summary, thermokarst lake drainage may induce higher carbon emission as $\mathrm{CO}_{2}$ and less $\mathrm{CH}_{4}$ emission in permafrost regions, while the vegetation resume in the original lake area may increase carbon sink. Thus, the landscape changes and their consequences owing to permafrost warming could not be simply defined because changes in permafrost-thermokarst-vegetation should be comprehensively considered. 


\section{$3 \mathrm{CH}_{4}$ emissions in seasonally ice-covered lakes}

Climate-sensitive northern lakes and ponds are critical components of $\mathrm{CH}_{4}$ release [96]. Significant seasonal $\mathrm{CH}_{4}$ emission has been found in temperate and subtropical lakes because of temperature differences $[50,53,60]$, whereas the situation in northern lakes should be different because of the long ice-covered period. Temperate lakes may have abundant $\mathrm{CH}_{4}$ oxidized or released to the atmosphere during the autumn overturn after $\mathrm{CH}_{4}$ storage in the summer stagnation period [26], while annual $\mathrm{CH}_{4}$ emissions in seasonally ice-covered northern dimictic lakes are characterized by two cycles of $\mathrm{CH}_{4}$ loss and buildup, namely $\mathrm{CH}_{4}$ loss during spring and autumn overturn with interim periods of buildup during summer stratification and under winter ice cover [56]. The winter ecology may be more active and play a more important role than expected; it can even influence the subsequent summer nutrient variables and biomass [30]. Conversely, reduced ice-cover dates in northern lakes [52] highlight an urgent need for research focused on under-ice $\mathrm{CH}_{4}$ dynamics and the contribution to annual emission.

\section{1 $\mathrm{CH}_{4}$ accumulation under ice and spring emission}

In boreal, Arctic, and many mountainous regions, lakes are covered by ice for a major part of the year. In lakes, $\mathrm{CH}_{4}$ is typically produced in anoxic bottom sediments by methanogenic microbes and can be released to the atmosphere by diffusion, vascular transport through aquatic plants, or ebullition (bubbling) in the open-water season [3]. While in most cases, the atmospheric exchange is limited when the ice on, and gases are trapped in the ice and underlying water (Fig. 2), with a little part escape through openings in the ice owing to ice cracks caused by increased pressure and/or warm waters from inflows and frequent $\mathrm{CH}_{4}$ bubbling [88], as well as from emergent vegetation through the ice [48]. Water-dissolved $\mathrm{CH}_{4}$ that diffuses from the sediment accumulates in the water column beneath the ice, as well as the ebullition $\mathrm{CH}_{4}$. In the early winter when ice is forming, bubbles are encapsulated by downwardgrowing lake ice, and then bubbles are trapped beneath the ice wall with a part dissolving into the water column [90]. If $\mathrm{CH}_{4}$ escaped oxidation under ice and during the ice out, $\mathrm{CH}_{4}$ accumulation under the ice could result in gas "storage," and large diffusion emissions occur when the ice melts in spring. This emission is often enhanced by full or partial lake overturn $[43,56,81]$. Overturn can cause oxygenation, potentially removing $\mathrm{CH}_{4}[28,68]$, but it can also efficiently transport gases from the lake bottom throughout the water column onto the lake surface before diffusing to the atmosphere [26]. Consequently, $\mathrm{CH}_{4}$ trapped during winter can be efficiently released during spring when ice melts and water mixes.

Numerous studies have pointed out the importance of $\mathrm{CH}_{4}$ accumulation under ice and emission during spring ice thaw, but their contribution to annual $\mathrm{CH}_{4}$ emission

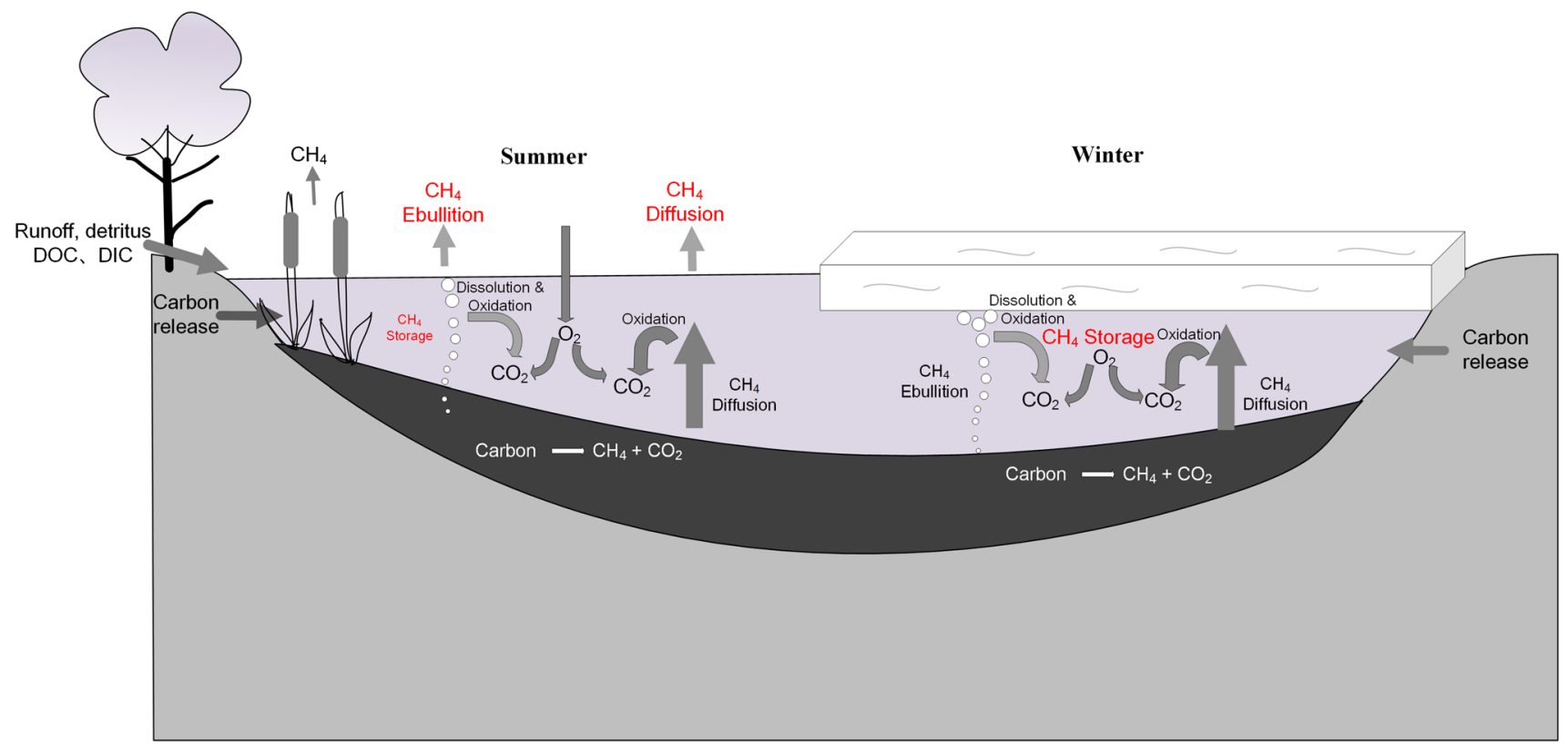

Fig. 2 Methane dynamics in northern seasonally ice-covered lakes during the summer and winter 
remains uncertain for lakes on a regional or larger spatial scale. Thus, more studies covering the whole year and accounting for $\mathrm{CH}_{4}$ emission during the ice-out and autumnal mixing period are needed to better assess the contribution of northern lakes to the global carbon cycle, and their sensitivity to climate change. In the present work, we compiled published studies inferring quantified $\mathrm{CH}_{4}$ emission for both the ice-melt and open-water periods. The method used is similar to that in Denfeld et al. [18] but with supplementation of newly published data. Ice melt refers to springtime when the start of ice thaw until complete ice off. Open-water time is ice free that includes the summer and the possible autumn turnover period. We obtained data for 261 lakes with 265 data points (Table 1 and Supporting Information Table S1). Previous studies estimated the spring efflux by using bubble traps under the ice or floating chambers, as well as by sampling $\mathrm{CH}_{4}$ dissolved in the lake water right before and after ice melt or by monitoring $\mathrm{CH}_{4}$ fluxes with eddy covariance [34]. Just like that in Denfeld et al. [18], we also calculated the percentage contribution of ice-melt flux to annual $\mathrm{CH}_{4}$ emission to reduce the uncertainty between different methods used to estimate $\mathrm{CH}_{4}$ fluxes. Results show that the icemelt emission contribution ranges from 0 to $100 \%$, with an average of $28 \%$ and a median of $18 \%$. There were $23 \%$ observations of ice-melt $\mathrm{CH}_{4}$ emission that had annual emission contribution more than $50 \% . \mathrm{CH}_{4}$ ebullition is considered only in limited studies, and the estimated icemelt $\mathrm{CH}_{4}$ emission contribution that includes ebullition is slightly lower or higher than the estimates that do not include ebullition (the differences were lower than 10\%) depending on the influence of ebullition on $\mathrm{CH}_{4}$ flux in ice-melt and ice-free periods (Table S1).

Studies about ice-melt lake $\mathrm{CH}_{4}$ emission have been primarily conducted in Finland and Sweden, Siberia, and northern North America (Table 1). Higher $\mathrm{CH}_{4}$ emission occurs in lakes located in Alaska, which has yedoma-sediment distribution [99] and permafrost-affected regions in Western Siberia [77]. Moreover, the ice-melt period $\mathrm{CH}_{4}$ emission contribution has no obvious difference among various study areas, except the high value in the Minnesota, USA, although the limited measurement in this area precludes further comparison (Table 1).

It should be noted that the spring ice-melt $\mathrm{CH}_{4}$ emission may be underestimated for the following seasons. Firstly, the $\mathrm{CH}_{4}$ ebullition through open hole in winter lake ice and the ice-bubble storage [91] are tend to be neglected when using quantified carbon gas storage before and after ice-out to estimate the spring efflux [34, 43]. Secondly, the unfreezing or ice-out period is brief for most northern lakes, during which considerable amounts of gas are emitted rapidly, while at this time the lakes are inaccessible due to the floating ice. Hence, it is urgent to develop better methods to capture this critical and challenging period [66].

\subsection{The possible influencing factors for ice-melt $\mathrm{CH}_{4}$ emission}

\subsubsection{Ice-melt $\mathrm{CH}_{4}$ emission versus lake area and depth}

Previous studies estimating spring efflux have found the relationships of ice-melt $\mathrm{CH}_{4}$ flux with physical lake characteristics. For example, Michmerhuizen et al. [56] considered that $\mathrm{CH}_{4}$ emission per unit area decreases with increased lake area. More studies have focused on ice-melt carbon emission versus lake depth. The study on three lakes in northern Sweden by Jansen et al. [34] concluded that spring $\mathrm{CH}_{4}$ emission contribution is higher in deep lakes than in shallow ones. However, the study of Juutinen et al. [40] involving 207 Finnish lakes suggested that very humic, shallow lakes have more $\mathrm{CH}_{4}$ storage in late winter-spring period than in summer-autumn. Recently, Prèskienis et al. [66] pointed out that water body morphology could strongly affect the seasonal patterns of $\mathrm{CH}_{4}$ flux through the effect on the mixing regime.

Here, we examined the relationships between ice-melt $\mathrm{CH}_{4}$ emission flux/ contribution and lake area/ maximum depth, and found relatively high spring ice-melt $\mathrm{CH}_{4}$ emission from small and shallow lakes (Fig. 3). Similar results

sion to annual emission expressed as mean and median values. The ebullition flux is not included

Northern lakes' $\mathrm{CH}_{4}$ emissions at ice-melt and ice-free m different study areas expressed as average \pm standard deviation, and the percentage contribution of ice-melt $\mathrm{CH}_{4}$ emis-

\begin{tabular}{llcccc}
\hline Lake number & Study area & Ice melt $\left(\mathrm{mmol} \mathrm{m}^{-2}\right)$ & Ice free $\left(\mathrm{mmol} \mathrm{m}^{-2}\right)$ & Contribution $(\%)$ & References \\
\hline 16 & Alaska, USA & $364.1 \pm 934.5$ & $1423.8 \pm 3666.5$ & $16($ median $=14)$ & {$[65,78]$} \\
10 & Northern Canada & $113.3 \pm 136.5$ & $266.4 \pm 377.5$ & $29($ median $=18)$ & {$[47,95,16,55]$} \\
2 & Minnesota, USA & $240 \pm 28.3$ & $110 \pm 70.7$ & 70 & {$[81]$} \\
29 & Western Siberia & $511.0 \pm 598.1$ & $3258.3 \pm 3203.1$ & $19($ median $=17)$ & {$[77]$} \\
204 & Finland \& Sweden & $90.2 \pm 104.3$ & $134.3 \pm 151.2$ & $29($ median $=18)$ & {$[6,18,19,31,33$,} \\
& & & & $34,39-43,48$, \\
\end{tabular}



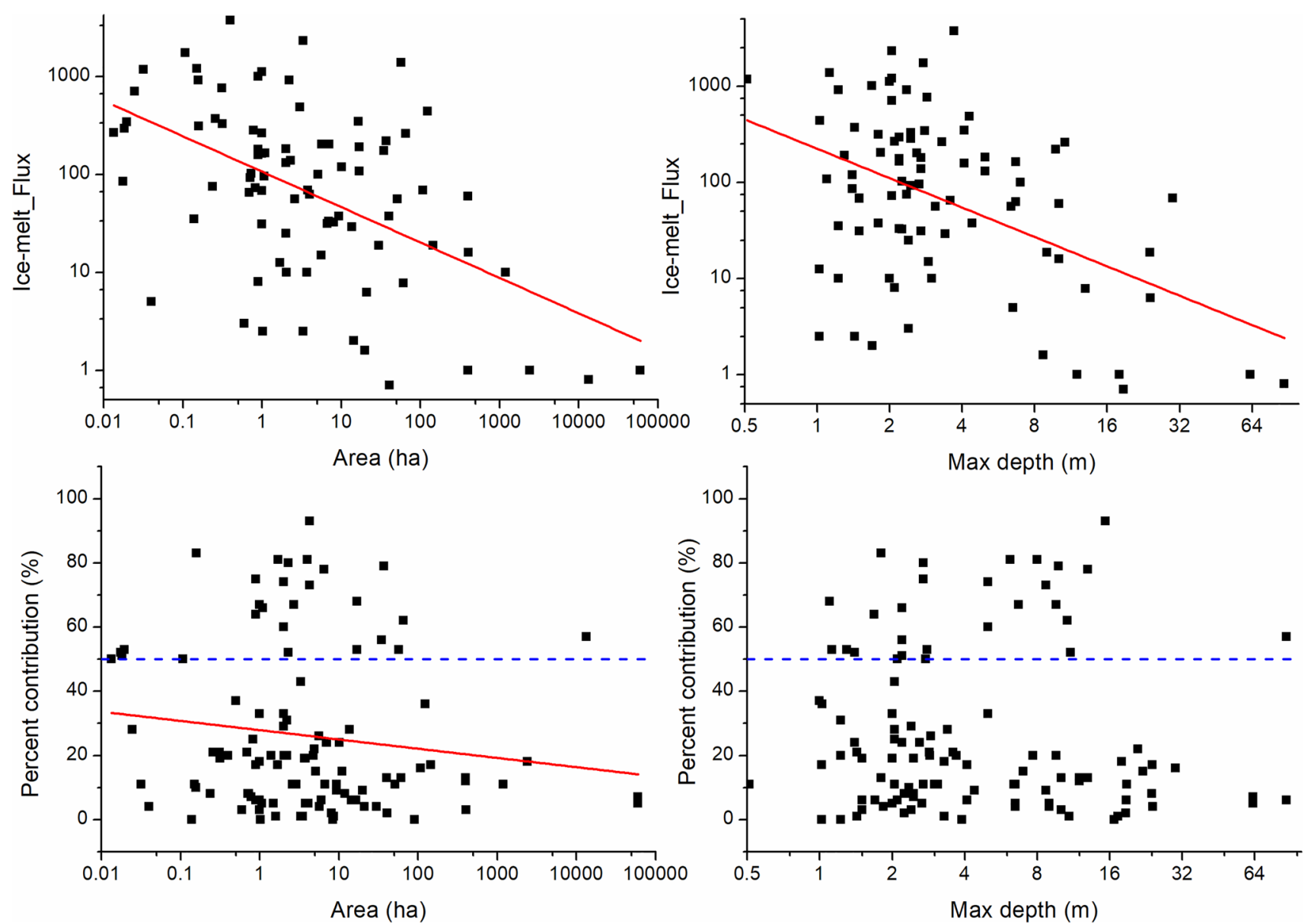

Fig. 3 Ice-melt $\mathrm{CH}_{4}$ emission flux $\left(\mathrm{mmol} \mathrm{m}^{-2}\right)$ and the percentage contribution in relation to lake area and maximum depth. Red lines are linear fits of all data; blue dash lines equal to $50 \%$ contribution. Note logarithmic axes

were reported for $\mathrm{CH}_{4}$ fluxes in the ice-free period in Wik et al. [96]. While different from the results in Wik et al. [96] that found weaker effect of lake area on $\mathrm{CH}_{4}$ fluxes than maximum depth, our results showed slightly greater effect of lake area (general linear model, $R^{2}=0.29$ ) than maximum depth (general linear model, $R^{2}=0.23$ ) on ice-melt $\mathrm{CH}_{4}$ fluxes. This finding is consistent with the discussion in Denfeld et al. [18] that small lakes often have incomplete autumn mixing and faster ice development, due to the characteristics of well shelter from the wind and rapid cooling, which may result in high $\mathrm{CH}_{4}$ concentrations under ice. However, we found weak or no correlation between the contribution percentage and lake characteristics (for the lake area, general linear model, $R^{2}=0.01$ ) (Fig. 3). This result may be explained by the similar effects of lake morphology on $\mathrm{CH}_{4}$ fluxes in the spring ice-melt and ice-free periods. Figure 3 also shows that the over $50 \%$ ice-melt $\mathrm{CH}_{4}$ emission contributions are mostly within the areas of $0.1-100$ ha and maximum depths of 1-10 m, indicating the potential of higher spring $\mathrm{CH}_{4}$ emission contribution in shallow and small lakes. However, these results also suggest the existence of other factors that influence ice-melt $\mathrm{CH}_{4}$ emission.

\subsubsection{Ice-melt $\mathrm{CH}_{4}$ emission versus $\mathrm{CH}_{4}$ oxidation}

The under-ice accumulation of $\mathrm{CH}_{4}$ during ice cover within a lake is influenced by the rates of $\mathrm{CH}_{4}$ production and oxidation. $\mathrm{CH}_{4}$ oxidation is proved to occur at under ice low temperatures [67] and methanotrophs are highly active in ice-covered lake water [41]. The presence of ice impeded $\mathrm{CH}_{4}$ diffusion and ebullition, resulting in $\mathrm{CH}_{4}$ accumulation under ice. Hence, different from the $\mathrm{CH}_{4}$ limitation in summer, aerobic $\mathrm{CH}_{4}$ oxidation is thought to be primarily controlled by the redox condition in the winter [54]. The under-ice water oxygen concentration is related to respiration and photosynthesis, as well as water-column volume. Hence, $\mathrm{CH}_{4}$ oxidation during ice cover may vary among shallow and deep lakes; the prevailing low oxygen concentration in the shallow lakes may induce to $\mathrm{CH}_{4}$ oversaturation under ice. For example, Phelps et al. [65] explored several shallow lakes and found the decline of 
oxygen levels after ice cover combined with increased $\mathrm{CH}_{4}$ levels following lake anoxia, and they considered that the marked increase in $\mathrm{CH}_{4}$ under the ice is due more to decreased rates of $\mathrm{CH}_{4}$ oxidation than to increased rates of $\mathrm{CH}_{4}$ production. In contrast, Striegl and Michmerhuizen [81] examined two larger and deeper lakes $(\sim 10 \mathrm{~m}$ maximum depth), and found that complete anoxia does not commonly occur in the water column; $\mathrm{CH}_{4}$ oxidation potential is continuously present all the time.

Apart from interior processes under ice, the water-column redox condition is also influenced by the lake-mixing event. A complete spring turnover of the water column brings oxygen to the hypolimnion and may result in an oxic condition in the hypolimnion during summer. By contrast, short or incomplete spring turnover may accompany the anoxic condition in the hypolimnion in the summer [41]. Similarly, the autumn turnover could probably influence the redox condition during winter ice cover, which is directly linked to $\mathrm{CH}_{4}$ oxidation and accumulation under ice. The study of Kankaala et al. [41] in a small, shallow lake that has incomplete spring water-column mixing revealed that the total $\mathrm{CH}_{4}$ consumption in the water column during the winter ice-covered period is higher than the efflux to the atmosphere in spring, and that $79 \% \mathrm{CH}_{4}$ is consumed in the water column on an annual scale. Although water-column mixing upon ice melt tends to release $\mathrm{CH}_{4}$ accumulated in the bottom waters directly into the atmosphere, increased potential of $\mathrm{CH}_{4}$ oxidation in the water column could occur when water-column mixing occurs before the ice melt, but complete mixing is more commonly observed only at the time of ice melt [18].

Winter $\mathrm{CH}_{4}$ oxidation seems to play a more important role in lakes with high $\mathrm{CH}_{4}$ ebullition from the sediment because the dissolution of bubbles that accumulated under the ice increases the potential of $\mathrm{CH}_{4}$ oxidation. Model estimation has shown that 80 percent of $\mathrm{CH}_{4}$ in bubbles trapped by ice dissolves into the lake water under the ice, and about half of that is oxidized [28]. The recent study by Elder et al. [23] using the measurement of dissolved gas concentrations and their ${ }^{14} \mathrm{C}$ and ${ }^{13} \mathrm{C}$ isotopes showed that the winter ice forced $50 \%$ ebullition $\mathrm{CH}_{4}$ to be oxidized by the end of winter, and the other half is accumulated in the dissolved $\mathrm{CH}_{4}$ pool under ice. Apart from dissolution, $\mathrm{CH}_{4}$ trapped in bubbles could also be released through diffusion, contributing to $\mathrm{CH}_{4}$ accumulation in the ice-water interface, where significant $\mathrm{CH}_{4}$ oxidation may be fueled [67]. However, an incubation experiment for under-ice lake water revealed that elevated $\mathrm{CH}_{4}$ concentration in the oxic lake water could not sufficiently activate $\mathrm{CH}_{4}$ oxidation in some lakes with low phosphate concentrations, suggesting that $\mathrm{CH}_{4}$ oxidation does not depend on $\mathrm{CH}_{4}$ or oxygen availability in these lakes. While $\mathrm{CH}_{4}$ oxidation was restricted to three lakes, where the phosphate concentrations were highest, they speculated that available phosphate may potentially provide sufficient phosphorus to sustain fast-growing heterotrophs and slow-growing methanotrophs because all organisms require phosphorus for cell division, energy transformations, and cell maintenance [17]. The relationship between methanotrophs abundance and phosphate concentration was also found in other lakes [69].

In summary, $\mathrm{CH}_{4}$ oxidation under ice or during the ice melt could significantly decrease $\mathrm{CH}_{4}$ emission to the air, which depends on $\mathrm{CH}_{4}$ production, oxygen available, the extent of lake mixing, as well as the nutrients that may influence the methanotrophs. Besides, an increasing number of studies have confirmed cascading effects of lake ecology in the ice-cover and ice-free periods. For example, the dissolved oxygen concentration and thermodynamic could be influenced by former lake turnover [63], and the ice conditions, for instance, duration and thickness, have also been observed to affect the phytoplankton community in the subsequent ice-free seasons [20,27]. Nevertheless, we only have ambiguous knowledge on some important questions about $\mathrm{CH}_{4}$ and oxygen dynamics under ice, such as how autumn overturn affect winter oxygen concentration and how reduced ice-cover duration affect $\mathrm{CH}_{4}$ production in the next ice-free season.

\subsubsection{Ice-melt $\mathrm{CH}_{4}$ emission versus hydrological carbon input}

Apart from autochthonous carbon by photosynthesis, a large amount of carbon in the lake is from river inflow, that is allochthonous carbon. The evidence shows that global change in northern regions leads to reduced primary productivity, resulting in increased proportion of allochthonous dissolved organic matter supply to northern lakes [15]. The hydrological patterns may influence carbon loading to lakes [82] and carbon evasion from the lakes. The result of a process-oriented lake biogeochemical model suggests that increasing organic matter input from the catchment increases future $\mathrm{CH}_{4}$ emission in lakes [5]. Moreover, rivers could also directly bring dissolved carbon into the lake, especially for dissolved $\mathrm{CO}_{2}$ in groundwater and surface water, whereas the input of external source $\mathrm{CH}_{4}$ is thought to account for a smaller proportion than $\mathrm{CH}_{4}$ produced by anaerobic decomposition in lake sediment [81]. However, this viewpoint seems to be challenged when an extreme rain event occurs. After heavy rain, $\mathrm{CH}_{4}$ concentration in the metalimnion and epilimnion increases and exceeds the $\mathrm{CH}_{4}$ concentration in deeper water when the water column is stratified, indicating that $\mathrm{CH}_{4}$ may be transported from the external $[51,57]$.

Except for runoff, other factors such as atmospheric pressure and water-column stratification, which could 
influence lake surface $\mathrm{CH}_{4}$ concentration in heavy rain, have rarely been discussed. These factors are important because heavy rain accompanied with wind may break up the long-term temperature stratification, resulting in the come-up of bottom $\mathrm{CH}_{4}$. External dissolved organic carbon and $\mathrm{CH}_{4}$ import can also contribute to ice-melt $\mathrm{CH}_{4}$ emission. Abundant carbon received by groundwater and surface water input maintains methanogenesis during the ice-covered wintertime, inducing large lake $\mathrm{CH}_{4}$ storage in the late winter and emission to the atmosphere immediately following ice melt [81]. Denfeld et al. [19] found higher $\mathrm{CH}_{4}$ concentrations in surface waters during sporadic ice-melt events over winter and considered that hydrological inputs should be a key driver of belowice $\mathrm{CH}_{4}$ in the lake. Meanwhile, the effect of external $\mathrm{CH}_{4}$ or carbon input on $\mathrm{CH}_{4}$ emission at ice melt may depend on soil and landscape features, for example, whether the surrounding basin can export organic matter or $\mathrm{CH}_{4}$ into the lake.

\section{Summary}

We reviewed research on $\mathrm{CH}_{4}$ emission in northern thermokarst and seasonally ice-covered lakes. These topics are associated with a sense of urgency and societal need under observed and modeled permafrost warming, nearsurface permafrost degeneration, increased hydrological activity of thermokarst lakes, winter warming, and reduced ice-cover duration over the past decades [52, 76], 94]. We found the following key issues that need to be addressed to enhance our understanding of $\mathrm{CH}_{4}$ emission contributed by northern lakes.

(1) Ancient carbon stored in permafrost could be substantially emitted as carbon gas under climate warming. To determine the potential of ancient carbon emission, future research in the northern permafrost region must consider the thermokarst and lake-forming processes, the variable geological conditions, and the carbon dynamics of thermokarst lakes.

(2) The evolution trends of thermokarst lakes in continuous and discontinuous permafrost regions, such as the thermokarst lake expansion or drainage, and the corresponding influence on $\mathrm{CH}_{4}$ emission and feedback to future climate change should be explored.

(3) The cascading effects of lake ecology in the ice-cover and ice-free periods, and the influence on $\mathrm{CH}_{4}$ emission under climate change are observed.

(4) Large-scale studies on lake $\mathrm{CH}_{4}$ dynamics under ice and comparison with mechanisms in the icefree period (e.g., $\mathrm{CH}_{4}$ production and $\mathrm{CH}_{4}$ oxidation related to water temperature, redox condition, and nutrients) should be conducted.

Acknowledgements This study was funded by The National Key Research and Development Program of China (2019YFA0607100), the National Natural Science Foundation of China (42001091, 41842049), and the Postdoctoral Research Funding Program of Jiangsu Province (2020Z277).

\section{Declarations}

Conflict of interest On behalf of all authors, the corresponding author states that there is no conflict of interest.

Open Access This article is licensed under a Creative Commons Attribution 4.0 International License, which permits use, sharing, adaptation, distribution and reproduction in any medium or format, as long as you give appropriate credit to the original author(s) and the source, provide a link to the Creative Commons licence, and indicate if changes were made. The images or other third party material in this article are included in the article's Creative Commons licence, unless indicated otherwise in a credit line to the material. If material is not included in the article's Creative Commons licence and your intended use is not permitted by statutory regulation or exceeds the permitted use, you will need to obtain permission directly from the copyright holder. To view a copy of this licence, visit http://creativecommons. org/licenses/by/4.0/.

\section{References}

1. AMAP. (2017) Snow, water, ice and permafrost. Summary for Policy-makers (pp. 1-20). Oslo, Norway: Arctic Monitoring and Assessment Programme (AMAP)

2. Arp $C D$, Jones $B M$, Urban $F E$, Grosse $G$ (2011) Hydrogeomorphic processes of thermokarst lakes with grounded-ice and floatingice regimes on the Arctic coastal plain. Alask Hydrol Processes 25(15):2422-2438

3. Bastviken D, Cole J, Pace M, Tranvik L (2004) Methane emissions from lakes: dependence of lake characteristics, two regional assessments, and a global estimate. Global Biogeochem Cycles. https://doi.org/10.1029/2004GB002238

4. Bastviken D, Tranvik LJ, Downing JA, Crill PM, Enrich-Prast A (2011) Freshwater methane emissions offset the continental carbon sink. Science 331(6013):50

5. Bayer TK, Gustafsson E, Brakebusch M, Beer C (2019) Future carbon emission from boreal and permafrost lakes are sensitive to catchment organic carbon loads. J Geophys Res Biogeosci 124(7):1827-1848

6. Bellido JL, Tulonen T, Kankaala P, Ojala A (2009) $\mathrm{CO}_{2}$ and $\mathrm{CH}_{4}$ fluxes during spring and autumn mixing periods in a boreal lake (Pääjärvi, southern Finland). J Geophys Res Biogeosci 114:G04007. https://doi.org/10.1029/2009JG000923

7. Bouchard F, Francus P, Pienitz R, Laurion I, Feyte S (2014) Subarctic thermokarst ponds: investigating recent landscape evolution and sediment dynamics in thawed permafrost of Northern Québec (Canada). Arct Antarct Alp Res 46(1):251-271

8. Bowden WB (2010) Climate change in the arctic - permafrost, thermokarst, and why they matter to the non-arctic world. Geogr Compass 4(10):1553-1566

9. Breton J, Prairie Y, Vallières C, Laurion I (2009) Limnological properties of permafrost thaw ponds in northeastern Canada. Can J Fish Aquat Sci 66(10):1635-1648 
10. Brosius LS, Anthony KMW, Grosse G, Chanton JP, Meyer H (2012) Using the deuterium isotope composition of permafrost meltwater to constrain thermokarst lake contributions to atmospheric $\mathrm{CH} 4$ during the last deglaciation. J Geophys Res Biogeosci 117(G1):G01022

11. Bruhwiler $L$, Dlugokencky $E$, Masarie $K$, Ishizawa $M$, Andrews $A$, Miller J, Sweeney C, Tans P, Worthy D (2014) CarbonTracker-CH4: an assimilation system for estimating emissions of atmospheric methane. Atmos Chem Phys 14(16):8269-8293

12. Burn CR (2005) Lake-bottom thermal regimes, western Arctic coast, Canada. Permafrost Periglac Process 16:355-367

13. Carroll ML, Townshend JRG, Dimiceli CM, Loboda T, Sohlberg RA (2011) Shrinking lakes of the Arctic: Spatial relationships and trajectory of change. Geophys Res Lett. https://doi.org/10.1029/ 2011GL049427

14. Christensen TR (2004) Thawing sub-arctic permafrost: effects on vegetation and methane emissions. Geophys Res Lett. https:// doi.org/10.1029/2003GL018680

15. Creed IF, Bergstrom AK, Trick CG, Grimm NB, Hessen DO, Karlsson J, Kidd KA, Kritzberg E, McKnight DM, Freeman EC, Senar OE, Andersson A, Ask J, Berggren M, Cherif M, Giesler R, Hotchkiss ER, Kortelainen P, Palta MM, Vrede T, Weyhenmeyer GA (2018) Global change-driven effects on dissolved organic matter composition: implications for food webs of northern lakes. Glob Chang Biol 24(8):3692-3714

16. Demarty M, Bastien J, Tremblay A (2011) Annual follow-up of gross diffusive carbon dioxide and methane emissions from a boreal reservoir and two nearby lakes in Québec. Canada Biogeosciences 8(1):41-53

17. Denfeld BA, Ricão Canelhas $M$, Weyhenmeyer GA, Bertilsson S, Eiler A, Bastviken D (2016) Constraints on methane oxidation in ice-covered boreal lakes. J Geophys Res Biogeosci 121(7):1924-1933

18. Denfeld BA, Baulch HM, Del Giorgio PA, Hampton SE, Karlsson $J$ (2018) A synthesis of carbon dioxide and methane dynamics during the ice-covered period of northern lakes. Limnol Oceanogr Lett 3:117-131

19. Denfeld BA, Klaus M, Laudon H, Sponseller RA, Karlsson J (2018) Carbon dioxide and methane dynamics in a small boreal lake during winter and spring melt events. J Geophys Res Biogeosci 123(8):2527-2540

20. Dokulil MT, Herzig A (2009) An analysis of long-term winter data on phytoplankton and zooplankton in Neusiedler See, a shallow temperate lake. Austria Aquat Ecol 43(3):715-725

21. Elberling $B$, Michelsen A, Schädel C, Schuur EAG, Christiansen HH, Berg L, Tamstorf MP, Sigsgaard C (2013) Long-term $\mathrm{CO}_{2}$ production following permafrost thaw. Nat Clim Chang 3(10):890-894

22. Elder CD, Xu X, Walker J, Schnell JL, Hinkel KM, Townsend-Small A, Arp CD, Pohlman JW, Gaglioti BV, Czimczik CI (2018) Greenhouse gas emissions from diverse Arctic Alaskan lakes are dominated by young carbon. Nat Clim Change 8:166

23. Elder CD, Schweiger M, Lam B, Crook ED, Czimczik Cl (2019) Seasonal sources of whole-lake $\mathrm{CH} 4$ and $\mathrm{CO} 2$ emissions from interior Alaskan Thermokarst lakes. J Geophys Res Biogeosci 124:1209-1229

24. Estop-Aragones $C$, Olefeldt $D$, Abbott BW, Chanton JP, Czimczik $\mathrm{Cl}$, Dean JF, Egan JE, Gandois L, Garnett MH, Hartley IP, Hoyt A, Lupascu M, Natali SM, O'Donnell JA, Raymond PA, Tanentzap AJ, Tank SE, Schuur EAG, Turetsky M, Anthony KW (2020) Assessing the potential for mobilization of old soil carbon after permafrost thaw: a synthesis of $\mathrm{C}-14$ measurements from the northern permafrost region. Global Biogeochem Cycles 34(9):26

25. Etminan $M$ et al (2016) Radiative forcing of carbon dioxide, methane, and nitrous oxide: a significant revision of the methane radiative forcing. Geophys Res Lett. https://doi.org/ 10.1002/2016GL071930

26. Fernández JE, Peeters F, Hofmann H (2014) Importance of the autumn overturn and anoxic conditions in the hypolimnion for the annual methane emissions from a temperate lake. Environ Sci Technol 48(13):7297-7304

27. Gerten D, Adrian R (2000) Climate-driven changes in spring plankton dynamics and the sensitivity of shallow polymictic lakes to the North Atlantic oscillation. Limnol Oceanogr 45(5):1058-1066

28. Greene S, Anthony KMW, Archer D, Sepulveda-Jauregui A, Martinez-Cruz K (2014) Modeling the impediment of methane ebullition bubbles by seasonal lake ice. Biogeosciences 11(23):6791-6811

29. Grosse G, Jones B, Arp C (2013) Thermokarst lakes, drainage, and drained basins. Treatise Geomorphol 8:325-353

30. Hampton SE, Galloway AW, Powers SM, Ozersky T, Woo KH, Batt RD, Labou SG, O'Reilly CM, Sharma S, Lottig NR, Stanley $\mathrm{EH}$, North RL, Stockwell JD, Adrian R, Weyhenmeyer GA, Arvola L, Baulch HM, Bertani I, Bowman LL Jr, Carey CC, Catalan J, Colom-Montero W, Domine LM, Felip M, Granados I, Gries C, Grossart HP, Haberman J, Haldna M, Hayden B, Higgins SN, Jolley JC, Kahilainen KK, Kaup E, Kehoe MJ, Maclntyre S, Mackay AW, Mariash HL, McKay RM, Nixdorf B, Noges P, Noges T, Palmer M, Pierson DC, Post DM, Pruett MJ, Rautio M, Read JS, Roberts SL, Rucker J, Sadro S, Silow EA, Smith DE, Sterner RW, Swann GE, Timofeyev MA, Toro M, Twiss MR, Vogt RJ, Watson SB, Whiteford EJ, Xenopoulos MA (2017) Ecology under lake ice. Ecol Lett 20(1):98-111

31. Huttunen JT, Alm J, Liikanen A, Juutinen S, Larmola T, Hammar T, Silvola J, Martikainen PJ (2003) Fluxes of methane, carbon dioxide and nitrous oxide in boreal lakes and potential anthropogenic effects on the aquatic greenhouse gas emissions. Chemosphere 52(3):609-621

32. IPCC. (2014). Climate Change 2014: Synthesis Report. Contribution of Working Groups I, II and III to the Fifth Assessment Report of the Intergovernmental Panel on Climate Change. In Core Writing Team, R. K. Pachauri \& L. A. Meyer (Eds.), (pp. 151PP.). Geneva, Switzerland: IPCC

33. Jammet $M$, Crill P, Dengel S, Friborg T (2015) Large methane emissions from a subarctic lake during spring thaw: Mechanisms and landscape significance. J Geophys Res Biogeosci 120(11):2289-2305

34. Jansen J, Thornton BF, Jammet MM, Wik M, Cortes A, Friborg T, Maclntyre S, Crill PM (2019) Climate-sensitive controls on large spring emissions of $\mathrm{CH}_{4}$ and $\mathrm{CO}_{2}$ from northern lakes. J Geophys Res Biogeosci 124(7):2379-2399

35. Jones MC, Grosse G, Jones BM, Walter Anthony K (2012) Peat accumulation in drained thermokarst lake basins in continuous, ice-rich permafrost, northern Seward Peninsula, Alaska. J Geophys Res Biogeosci 117:G00M07. https://doi.org/10.1029/ 2011JG001766

36. Jorgenson MT, Shur YL, Pullman ER (2006) Abrupt increase in permafrost degradation in Arctic Alaska. Geophys Res Lett 33(2):L02503

37. Jorgenson MT, Shur Y (2007) Evolution of lakes and basins in northern Alaska and discussion of the thaw lake cycle. J Geophys Res 112:F02S17. https://doi.org/10.1029/2006JF000531

38. Jorgenson MT, Romanovsky V, Harden J, Shur Y, O'Donnell J, Schuur EAG, Kanevskiy M, Marchenko S (2010) Resilience and vulnerability of permafrost to climate change this article is one of a selection of papers from the dynamics of change in Alaska's boreal forests: resilience and vulnerability in response to climate warming. Can J For Res 40(7):1219-1236

39. Juutinen S, Alm J, Larmola T, Huttunen JT, Morero M, Martikainen PJ, Silvola J (2003). Major implication of the littoral 
zone for methane release from boreal lakes. Global Biogeochem Cycles 17(4):1117. https://doi.org/10.1029/2003GB0021 05

40. Juutinen S, Rantakari M, Kortelainen P, Huttunen JT, Larmola T, Alm J, Silvola J, Martikainen PJ (2009) Methane dynamics in different boreal lake types. Biogeosciences 6(2):209-223

41. Kankaala P, Huotari J, Peltomaa E, Saloranta T, Ojala A (2006) Methanotrophic activity in relation to methane efflux and total heterotrophic bacterial production in a stratified, humic, boreal lake. Limnol Oceanogr 51(2):1195-1204

42. Karlsson J, Christensen TR, Crill P, Förster J, Hammarlund D, Jackowicz-Korczynski M, Kokfelt U, Roehm C, Rosén P (2010) Quantifying the relative importance of lake emissions in the carbon budget of a subarctic catchment. J Geophys Res 115:G03006. https://doi.org/10.1029/2010JG001305

43. Karlsson J, Giesler R, Persson J, Lundin E (2013) High emission of carbon dioxide and methane during ice thaw in high latitude lakes. Geophys Res Lett 40(6):1123-1127

44. Kessler MA, Plug LJ, Walter Anthony KM (2012) Simulating the decadal- to millennial-scale dynamics of morphology and sequestered carbon mobilization of two thermokarst lakes in NW Alaska. J Geophys Res Biogeosci 117:G00M06. https://doi. org/10.1029/2011JG001796

45. Knoblauch C, Beer C, Sosnin A, Wagner D, Pfeiffer EM (2013) Predicting long-term carbon mineralization and trace gas production from thawing permafrost of Northeast Siberia. Glob Chang Biol 19(4):1160-1172

46. Kokelj SV, Jorgenson MT (2013) Advances in Thermokarst Research. Permafrost Periglac Process 24(2):108-119

47. Kuhlbusch T, Zepp RG (1999) Carbon trace gases in lake and beaver pond ice near Thompson, Manitoba. Can J Geophys Res Atmos 104(D22):27693-27698

48. Larmola T, Alm J, Juutinen S, Huttunen JT, Martikainen PJ, Silvola $\mathrm{J}$ (2004) Contribution of vegetated littoral zone to winter fluxes of carbon dioxide and methane from boreal lakes. J Geophys Res Atmos 109:D19102. https://doi.org/10.1029/2004JD004875

49. Lee H, Schuur EAG, Inglett KS, Lavoie M, Chanton JP (2012) The rate of permafrost carbon release under aerobic and anaerobic conditions and its potential effects on climate. Glob Change Biol 18(2):515-527

50. Li L, Xue B, Yao S, Tao Y, Yan R (2018) Spatial-temporal patterns of methane dynamics in Lake Taihu. Hydrobiologia 822:143-156

51. LóPez Bellido J, Tulonen T, Kankaala P, Ojala A (2013) Concentrations of $\mathrm{CO} 2$ and $\mathrm{CH} 4$ in water columns of two stratified boreal lakes during a year of atypical summer precipitation. Biogeochemistry 113(1-3):613-627

52. Magnuson JJ, Robertson DM, Benson BJ, Wynne RH, Livingstone DM, Arai T, Assel RA, Barry RG, Card V, Kuusisto E, Granin NG, Prowse TD, Stewart KM, Vuglinski VS (2000) Historical trends in lake and river ice cover in the Northern Hemisphere. Science 289(5485):1743-1746

53. Marinho CC, Palma Silva C, Albertoni EF, Trindade C, Esteves FDA (2009) Seasonal dynamics of methane in the water column of two subtropical lakes differing in trophic status. Br J Biol 69(2):281-287

54. Martinez-Cruz K, Sepulveda-Jauregui A, Walter Anthony K, Thalasso F (2015) Geographic and seasonal variation of dissolved methane and aerobic methane oxidation in Alaskan lakes. Biogeosciences 12(15):4595

55. Matveev A, Laurion I, Vincent WF (2019) Winter accumulation of methane and its variable timing of release from thermokarst lakes in subarctic Peatlands. J Geophys Res Biogeosci 124. https://doi.org/10.1029/2019JG005078

56. Michmerhuizen CM, Striegl RG, McDonald ME (1996) Potential methane emission from north-temperate lakes following ice melt. Limnol Oceanogr 41(5):985-991
57. Miettinen $\mathrm{H}$, Pumpanen J, Heiskanen JJ, Aaltonen $\mathrm{H}$, Mammarella I, Ojala A, Levula J, Rantakari M (2015) Towards a more comprehensive understanding of lacustrine greenhouse gas dynamics - two-year measurements of concentrations and fluxes of $\mathrm{CO}_{2}, \mathrm{CH}_{4}$ and $\mathrm{N}_{2} \mathrm{O}$ in a typical boreal lake surrounded by managed forests. Boreal Env Res 20:75-89

58. Moguel RG, Bass AM, Garnett MH, Pilote M, Keenan B, Matveev A, Douglas PMJ (2021) Radiocarbon data reveal contrasting sources for carbon fractions in Thermokarst lakes and rivers of eastern Canada (Nunavik, Quebec). J Geophys Res Biogeosci 126(4):16

59. Morgenstern A, Grosse G, Schirrmeister L (2008) Genetic, morphological, and statistical characterization of lakes in the permafrost-dominated Lena delta. Paper presented at the International Conference on Biomedical \& Pharmaceutical Engineering

60. Natchimuthu S, Sundgren I, Gålfalk M, Klemedtsson L, Crill P, Danielsson Å, Bastviken D (2016) Spatio-temporal variability of lake $\mathrm{CH} 4 f$ luxes and its influence on annual whole lake emission estimates. Limnol Oceanogr 61:S13-S26

61. O'Connor FM, Boucher O, Gedney N, Jones CD, Folberth GA, Coppell R, Friedlingstein P, Collins WJ, Chappellaz J, Ridley J, Johnson CE (2010) Possible role of wetlands, permafrost, and methane hydrates in the methane cycle under future climate change: a review. Rev Geophys 48:RG4005. https://doi.org/10. 1029/2010RG000326

62. Olefeldt D, Goswami S, Grosse G, Hayes D, Hugelius G, Kuhry P, McGuire AD, Romanovsky VE, Sannel AB, Schuur EA, Turetsky MR (2016) Circumpolar distribution and carbon storage of thermokarst landscapes. Nat Commun 7:13043

63. O'Reilly CM, Sharma S, Gray DK, Hampton SE, Read JS, Rowley RJ, Schneider P, Lenters JD, Mcintyre PB, Kraemer BM (2015) Rapid and highly variable warming of lake surface waters around the globe. Geophys Res Lett 42. https://doi.org/10. 1002/2015GL066235

64. Osterkamp TE (2007) Characteristics of the recent warming of permafrost in Alaska. J Geophysl Res Earth Surf 112:F02S02. https://doi.org/10.1029/2006JF000578

65. Phelps AR, Peterson KM, Jeffries MO (1998) Methane efflux from high-latitude lakes during spring ice melt. J Geophys Res Atmos 103(D22):29029

66. Préskienis V, Laurion I, Bouchard F, Douglas PMJ, Billett MF, Fortier D, Xu X (2021) Seasonal patterns in greenhouse gas emissions from lakes and ponds in a High Arctic polygonal landscape. Limnol Oceanogr 66:S117-S141. https://doi.org/ 10.1002/Ino.11660

67. Ricão Canelhas M, Denfeld BA, Weyhenmeyer GA, Bastviken D, Bertilsson S (2016) Methane oxidation at the water-ice interface of an ice-covered lake. Limnol Oceanogr 61(S1):S78-S90

68. Rudd JW, Hamilton R (1978) Methane cycling in a eutrophic shield lake and its effects on whole lake metabolism. Limnol Oceanogr 23(2):337-348

69. Sainur SM, Stefan B (2017) Seasonal variations in abundance and diversity of bacterial mathanotrophs in five temperate lakes. Front Microbiol 8:1-12

70. Saunois $M$, Bousquet $P$, Poulter $B$, Peregon $A$, Ciais $P$, Canadell JG, Dlugokencky EJ, Etiope G, Bastviken D, Houweling S, Janssens-Maenhout G, Tubiello FN, Castaldi S, Jackson RB, Alexe $M$, Arora VK, Beerling DJ, Bergamaschi P, Blake DR, Brailsford G, Brovkin V, Bruhwiler L, Crevoisier C, Crill P, Curry C, Frankenberg $C$, Gedney N, Höglund-Isaksson L, Ishizawa $M$, Ito $A$, Joos F, Kim H-S, Kleinen T, Krummel P, Lamarque J-F, Langenfelds R, Locatelli R, Machida T, Maksyutov S, McDonald KC, Marshall J, Melton JR, Morino I, Naik V, Doherty S, Parmentier F-JW, Patra PK, Peng C, Peng S, Peters GP, Pison I, Prigent C, Prinn R, Ramonet M, Riley WJ, Saito M, Schroeder R, Simpson IJ, Spahni R, Steele P, Takizawa A, Thornton BF, Tian H, Tohjima 
Y, Viovy N, Voulgarakis A, van Weele M, van der Werf G, Weiss R, Wiedinmyer C, Wilton DJ, Wiltshire A, Worthy D, Wunch DB, Xu X, Yoshida Y, Zhang B, Zhang Z, Zhu Q (2016) The global methane budget: 2000-2012. Earth Syst Sci Data Discuss 8:697-751

71. Schädel C, Schuur EA, Bracho R, Elberling B, Knoblauch C, Lee H, Luo Y, Shaver GR, Turetsky MR (2014) Circumpolar assessment of permafrost $C$ quality and its vulnerability over time using long-term incubation data. Glob Chang Biol 20(2):641-652

72. Schädel C, Bader MKF, Schuur EAG, Biasi C, Bracho R, Čapek P, De Baets S, Diáková K, Ernakovich J, Estop-Aragones C, Graham DE, Hartley IP, Iversen CM, Kane E, Knoblauch C, Lupascu M, Martikainen PJ, Natali SM, Norby RJ, O'Donnell JA, Chowdhury TR, Šantrůčková H, Shaver G, Sloan VL, Treat CC, Turetsky MR, Waldrop MP, Wickland KP (2016) Potential carbon emissions dominated by carbon dioxide from thawed permafrost soils. Nat Clim Chang 6(10):950-953

73. Schirrmeister L, Potsdam Germany Polar A, Research M (2013). Yedoma: late pleistocene ice-rich syngenetic permafrost of Beringia. In E. S.A. (Ed.), The Encyclopedia of Quaternary Science. Amsterdam: Elsevier. Vol. 3, pp. 542-552

74. Schuur EAG, Bockheim J, Canadell JG, Euskirchen E, Field CB, Goryachkin SV, Hagemann S, Kuhry P, Lafleur PM, Lee H, Mazhitova G, Nelson FE, Rinke A, Romanovsky VE, Shiklomanov N, Tarnocai C, Venevsky S, Vogel JG, Zimov SA (2008) Vulnerability of permafrost carbon to climate change: implications for the global carbon cycle. Bioscience 58(8):701-714

75. Schuur EAG, Abbott BW, Bowden WB, Brovkin V, Camill $P$, Canadell JG, Chanton JP, Chapin FS, Christensen TR, Ciais P, Crosby BT, Czimczik Cl, Grosse G, Harden J, Hayes DJ, Hugelius $G$, Jastrow JD, Jones JB, Kleinen T, Koven CD, Krinner G, Kuhry $P$, Lawrence DM, McGuire AD, Natali SM, O'Donnell JA, Ping CL, Riley WJ, Rinke A, Romanovsky VE, Sannel ABK, Schädel C, Schaefer K, Sky J, Subin ZM, Tarnocai C, Turetsky MR, Waldrop MP, Walter Anthony KM, Wickland KP, Wilson CJ, Zimov SA (2013) Expert assessment of vulnerability of permafrost carbon to climate change. Clim Change 119(2):359-374

76. Schuur EA, McGuire AD, Schadel C, Grosse G, Harden JW, Hayes DJ, Hugelius G, Koven CD, Kuhry P, Lawrence DM, Natali SM, Olefeldt D, Romanovsky VE, Schaefer K, Turetsky MR, Treat CC, Vonk JE (2015) Climate change and the permafrost carbon feedback. Nature 520(7546):171-179

77. Serikova S, Pokrovsky OS, Laudon H, Krickov IV, Lim AG, Manasypov RM, Karlsson J (2019) High carbon emissions from thermokarst lakes of Western Siberia. Nat Commun 10:1552. https://doi. org/10.1038/s41467-019-09592-1

78. Sepulveda-Jauregui A, Walter Anthony KM, Anthony P, Grosse G, Chanton J (2015) Methane and carbon dioxide emissions from 40 lakes along a north-south latitudinal transect in Alaska. Biogeosciences 12(11):3197-3223

79. Smith LC, Sheng Y, MacDonald GM, Hinzman LD (2005) Disappearing Arctic lakes. Science 308(5727):1429-1429

80. Strauss J, Schirrmeister L, Grosse G, Wetterich S, Ulrich M, Herzschuh U, Hubberten HW (2013) The deep permafrost carbon pool of the Yedoma region in Siberia and Alaska. Geophys Res Lett 40(23):6165-6170

81. Striegl RG, Michmerhuizen CM (1998) Hydrologic influence on methane and carbon dioxide dynamics at two north-central Minnesota lakes. Limnol Oceanogr 43(7):1519-1529

82. Tranvik LJ, Downing JA, Cotner JB, Loiselle SA, Striegl RG, Ballatore TJ, Dillon P, Finlay K, Fortino K, Knoll LB (2009) Lakes and reservoirs as regulators of carbon cycling and climate. Limnol Oceanogr 54(6part2):2298-2314

83. Treat CC, Natali SM, Ernakovich J, Iversen CM, Lupascu M, McGuire AD, Norby RJ, Roy Chowdhury T, Richter A, Santruckova H, Schadel C, Schuur EAG, Sloan VL, Turetsky MR, Waldrop MP
(2015) A pan-Arctic synthesis of $\mathrm{CH} 4$ and $\mathrm{CO} 2$ production from anoxic soil incubations. Glob Chang Biol 21(7):2787-2803

84. Turetsky MR, Wieder RK, Vitt DH, Evans RJ, Scott KD (2007) The disappearance of relict permafrost in boreal north America: Effects on peatland carbon storage and fluxes. Glob Change Biol 13(9):1922-1934

85. van der Molen MK, van Huissteden J, Parmentier FJW, Petrescu AMR, Dolman AJ, Maximov TC, Kononov AV, Karsanaev SV, Suzdalov DA (2007) The growing season greenhouse gas balance of a continental tundra site in the Indigirka lowlands. NE Siberia Biogeosci 4(6):985-1003

86. van Huissteden J, Maximov TC, Dolman AJ (2005) High methane flux from an arctic floodplain (Indigirka lowlands, eastern Siberia). J Geophys Res Biogeosci 110:G02002. https://doi.org/ 10.1029/2005JG000010

87. van Huissteden J, Berrittella C, Parmentier FJW, Mi Y, Maximov TC, Dolman AJ (2011) Methane emissions from permafrost thaw lakes limited by lake drainage. Nat Clim Chang 1(2):119-123

88. Walter KM, Zimov SA, Chanton JP, Verbyla D, Chapin FS III (2006) Methane bubbling from Siberian thaw lakes as a positive feedback to climate warming. Nature 443(7107):71-75

89. Walter Anthony KM, Smith LC, Chapin FS 3rd (2007) Methane bubbling from northern lakes: present and future contributions to the global methane budget. Philos Trans A Math Phys Eng Sci 365(1856):1657-1676

90. Walter Anthony KM, Chanton JP, Chapin FS, Schuur EAG, Zimov SA (2008) Methane production and bubble emissions from arctic lakes: Isotopic implications for source pathways and ages. J Geophys Res 114:G04007. https://doi.org/10.1029/2009JG0009 23

91. Walter Anthony KM, Vas DA, Brosius L, Chapin FS, Zimov SA, Zhuang Q (2010) Estimating methane emissions from northern lakes using ice-bubble surveys. Limnol Oceanogr Methods 8(6):592-609

92. Walter Anthony KM, Anthony P, Grosse G, Chanton J (2012) Geologic methane seeps along boundaries of Arctic permafrost thaw and melting glaciers. Nat Geosci 5(6):419-426

93. Walter Anthony KM, Zimov SA, Grosse G, Jones MC, Anthony PM, Chapin FS III, Finlay JC, Mack MC, Davydov S, Frenzel P, Frolking S (2014) A shift of thermokarst lakes from carbon sources to sinks during the Holocene epoch. Nature 511(7510):452-456

94. Walter Anthony KM, Daanen R, Anthony P, von Deimling TS, Ping C-L, Chanton JP, Grosse G (2016) Methane emissions proportional to permafrost carbon thawed in Arctic lakes since the 1950s. Nat Geosci 9(9):679

95. Weyhenmeyer Constanze E (1999) Methane emissions from beaver ponds: Rates, patterns, and transport mechanisms. Global Biogeochem Cycles 13(4):1079-1090

96. Wik M, Varner RK, Anthony KW, MacIntyre S, Bastviken D (2016) Climate-sensitive northern lakes and ponds are critical components of methane release. Nat Geosci 9(2):99-105

97. Zhang T, Barry RG, Knowles K, Heginbottom JA (2008) Statistics and characteristics of permafrost and ground-ice distribution in the Northern Hemisphere. Polar Geogr 31:47

98. Zimov SA, Davydov SP, Zimova GM, Davydova Al, Schuur EAG, Dutta K, Chapin FS (2006a) Permafrost carbon: stock and decomposability of a globally significant carbon pool. Geophys Res Lett 33:L20502. https://doi.org/10.1029/2006GL027484

99. Zimov SA, Schuur EA, Chapin FS III (2006) Permafrost and the global carbon budget. Science (Washington) 312(5780):1612-1613

Publisher's Note Springer Nature remains neutral with regard to jurisdictional claims in published maps and institutional affiliations. 